\title{
Resistance jump training may reverse the weakened biomechanical behavior of tendons of diabetic Wistar rats
}

\author{
O treinamento de salto de resistência pode reverter o comportamento biomecânico \\ enfraquecido dos tendões de ratos Wistar diabéticos \\ El entrenamiento de salto de resistencia puede revertir el comportamiento biomecánico \\ debilitado de los tendones de las ratas Wistar diabéticas \\ Raissa Thais Belarmino Silva', Patrícia Verçoza de Castro', Marcos Paulo Galdino Coutinho', \\ Ana Camila Nobre de Lacerda Brito', Márcio Almeida Bezerra², Silvia Regina Arruda de Moraes
}

\begin{abstract}
Background: resistance training is widely applied in non-diabetic physical protocol showing effectiveness in improving the tendon tissue. To address this gap, we assessed the effects of resistance training on aquatic environment, on the biomechanical properties of the calcaneal tendon of diabetic Wistar rats. Methods: 59 male Wistar rats were evaluated for 60 days, they were randomly divided into the following groups: Sedentary Control Group (SCG, n=15), Sedentary Diabetic Group (SDG, n=15), Trained Control Group (TCG, n=14) and Trained Diabetic Group (TDG, $\mathrm{n}=15$ ). After randomization the animals from the SDG and the TDG were induced to Diabetes Mellitus by intraperitoneal injection of Streptozotocin ( $60 \mathrm{mg} / \mathrm{kg}$ ). The animals on the trained groups performed resistance exercise that consisted of jumping in an aquatic environment. After nine weeks the calcaneal tendons were collected and tractioned on a conventional mechanical testing machine. Results: the analysis of biomechanical parameters showed lower values in elastic modulus ( $p=0.000)$, maximum strength tension $(p=0.000)$ and energy/area $(p=0.008)$ in TDG compared to SDG in addition to an increase on the cross-sectional area $(p=0.002)$. There was no difference for the specific deformation variable. Conclusion: the training protocol used restored some biomechanical parameters of the calcaneal tendon in rats induced to diabetes, thus, resulting in an improvement of its mechanical efficiency.
\end{abstract}

Keywords | Diabetes Mellitus; Resistance Training; Connective Tissue; Animal Model.
RESUMO | Antecedentes: o treinamento de resistência é amplamente aplicado no protocolo físico não diabético mostrando eficiência na melhoria do tecido do tendão. Para abordar esta lacuna, avaliamos os efeitos do treinamento de resistência no ambiente aquático, nas propriedades biomecânicas do tendão calcâneo de ratos Wistar diabéticos. Métodos: 59 ratos Wistar machos foram avaliados por 60 dias, os quais foram divididos aleatoriamente nos seguintes grupos: Grupo de Controle Sedentário (GCS, n=15), Grupo Diabético Sedentário (GDS, n=15), Grupo de Controle Treinado (GCT, n=14) e Grupo Diabético Treinado (GDT, n=15). Após a randomização, os animais do GDS e do CDT foram induzidos a diabetes mellitus por injeção intraperitoneal de Streptozotocin (60mg/ kg). Os animais dos grupos treinados realizaram exercícios de resistência que consistiam em saltar em um ambiente aquático. Após nove semanas, os tendões calcaneares foram coletadose tracionados em uma máquina convencional de teste mecânico. Resultados: A análise dos parâmetros biomecânicos mostrou valores mais baixos em módulo elástico $(p=0,000)$, tensão máxima de força $(p=0,000)$ e energia/área $(p=0,008)$ em GDT em comparação com GDS, além de um aumento na área transversal $(p=0,002)$. Não houve diferença para a variável de deformação específica. Conclusão: o protocolo de treinamento usado restaurou alguns parâmetros biomecânicos do tendão calcâneo em ratos induzidos a diabetes, resultando, assim, na melhoria da eficiência mecânica.

Descritores | Diabetes Mellitus; Treinamento de Resistência; Tecido Conjuntivo; Modelo Animal. 
RESUMEN | Antecedentes: el entrenamiento de resistencia se aplica ampliamente en el protocolo físico no diabético mostrándose la efectividad en la mejora del tejido del tendón. Para abordar esta brecha, evaluamos los efectos del entrenamiento de resistencia en el ambiente acuático, en las propiedades biomecánicas del tendón calcáneo de las ratas Wistar diabéticas. Métodos: se evaluaron 59 ratas Wistar machos durante 60 días, éstes se dividieron aleatoriamente en los siguientes grupos: Grupo de Control Sedentario (GCS, n=15), Grupo Diabético Sedentario (GDS, n=15), Grupo de Control Entrenado (GCE, n=14) y Grupo Diabético Entrenado (GDE, n=15). Después de la aleatorización, los animales del GDS y del GDE se indujeron a diabetes mellitus por inyección intraperitoneal de Streptozotocin $(60 \mathrm{mg} / \mathrm{kg})$. Los animales de los grupos entrenados realizaron ejercicios de resistencia que consistían en saltar en un ambiente acuático. Después de nueve semanas, se recogieron y traccionaron los tendones calcaneales en una máquina convencional de prueba mecánica. Resultados: El análisis de los parámetros biomecánicos mostró valores más bajos en módulo elástico ( $\mathrm{p}=0.000$ ), tensión de fuerza máxima ( $p=0.000)$ y energía/área ( $p=0.008$ ) en GDE en comparación con GDS, además de un aumento en la área transversal ( $p=0.002)$. No hubo diferencia para la variable de deformación específica. Conclusión: el protocolo de entrenamiento utilizado restauró algunos parámetros biomecánicos del tendón calcáneo en ratas inducidas a la diabetes, lo que resultó en una mejora de su eficiencia mecánica.

Palabras clave | Diabetes Mellitus; Entrenamiento de Resistencia; Tejido Conjuntivo; Modelo Animal.

\section{INTRODUCTION}

Complications of the skeletal muscle system due to the process of chronicity of Diabetes Mellitus (DM) can aggravate the general health state of diabetic individuals, especially when the tendinous structure is the target of these metabolic complications ${ }^{1-4}$.

The mechanism by which diabetes acts on the structure of the collagen of tendons has not been fully understood yet ${ }^{1,4-7}$. However, there is evidence that hyperglycemia can cause an accelerated process of nonenzymatic glycation and deposition of collagen in a disorganized form in periarticular connective tissues ${ }^{6,8,9}$. Significant changes are being demonstrated on the biomechanical properties of the calcaneal tendon of animals induced to diabetes, recently. These changes on the viscoelastic capability of the tendon can reduce the transmission of energy and predispose the tendon to early breakage when subjected to mechanical stress ${ }^{10}$.

On the other hand, literature demonstrates the beneficial effects of physical training, providing control of DM through its facilitation of peripheral uptake of glucose and metabolism of glycogen and protein ${ }^{11,12}$. Therefore, training is of great importance to control diabetes by significantly raising the energy needs of the organism, thus requiring significant acute changes in cellular metabolism and neuroendocrine control ${ }^{13}$. Additionally, there is evidence that physical training is important to increase insulin content, promoting greater secretion of this hormone in isolated pancreatic islets in patients with diabetes mellitus, type $1^{14}$.
Regarding the tendinous complex, a recent systematic review demonstrated increased load borne by the tendon in response to resistance or endurance training, specifically on physical training in an aquatic environment ${ }^{19}$. Increases on the tendon elasticity module were found, which does not trigger losses on the energy storage of the tendon. Theoretically, this would promote an improvement on the transmission of energy from the muscle to the bone framework structures ${ }^{20}$. Furthermore, an improvement of biomechanical parameters of the calcaneal tendon was found, when compared to control groups when studying diabetic animals subjected to resistance training on a treadmill, this could be a sign of the structural re-establishment of the tendinous complex ${ }^{21}$.

On the other hand, resistance training, which is widely applied and studied on literature, showed that there are evidences of structural and biochemical plasticity of tendons in response to resistance training only in non-diabetic animals ${ }^{15-18}$, leaving a gap about possible adaptations that resistance training might promote on metabolic pathologies that affect all systems.

The calcaneal tendon plays an important role in locomotion and its elasticity increases the efficiency of muscles during activity cycles ${ }^{22-24}$. However, in diabetes there are biomechanical losses that can dramatically compromise the performance and function of this tendon. Thus, with the objective of this study was to assess whether the resistance jump training in an aquatic environment has some effect on the biomechanical properties of the calcaneal tendon of rats experimentally induced to DM. 


\section{METHODOLOGY}

\section{Sample}

A total of 59 healthy, male rats of the race Rattus Norvegicus Albinus, Wistar lineage were used, they were aged 60 days and had approximately $250 \mathrm{~g}$ in weight, they were kept in the experimentation vivarium of the Department of Anatomy in cages (groups of four animals) in an inverted light/dark lighting cycle every $12 \mathrm{~h}$ and the temperature was maintained at $23 \pm 1^{\circ} \mathrm{C}$. The mice were given a diet composed of feed and water ad libitum.

The procedures for handling and care of the animals were in accordance to the rules of the National Institute of Health Guide for Care and Use of Laboratory Animals and were approved by the Committee of Ethics in Animal Experimentation (CEEA) of the Universidade Federal de Pernambuco - UFPE (Protocolo no: 23076.026692/2012-80).

The animals were divided into four groups: Sedentary Control Group (SCG, n=15), Sedentary Diabetic Group (SDG, $\mathrm{n}=15$ ), uTrained Control Group (TCG, n=14) and Trained Diabetic Group (TDG, $\mathrm{n}=15$ ). The animals in the SCG and SDG were restricted to free movement within their cages. Animals in the trained groups (TCG and TDG) underwent training for nine weeks.

\section{Induction of Diabetes and blood glucose control}

The animals in the SDG and TDG were induced to diabetes mellitus, type 1 by intraperitoneal injection of Streptozotocin (Sigma Chemical Co., USA) diluted in $10 \mathrm{mM}$ sodium citrate buffer and $\mathrm{pH} 4.5$ (single dose of $60 \mathrm{mg} / \mathrm{kg}$ of body weight of the animal) ${ }^{25}$. The only animals that were included in the study were the ones that showed blood glucose levels above $200 \mathrm{mg} / \mathrm{dL}^{26}$. Animals belonging to the SCG and TCG received an equivalent dose of sodium citrate buffer solution, aiming to replicate the stress caused to diabetic groups.

The animals were submitted to glycemic assessment after a $12 \mathrm{~h}$ period of fasting during the weeks following the induction. Once a week, a drop of blood was taken from the tail of the animals, it was then analyzed using a reagent test strip (Accu-Check Activ).

\section{Resistance training}

One week after induction, the non-sedentary animals underwent a resistance training protocol that lasted nine weeks, with a frequency of five sessions per week, which consisted of performing jumps in a cylindrical tank with $20 \mathrm{~cm}$ diameter and $70 \mathrm{~cm}$ length, with a weight coupled to the chest of the animal through a vest. The first week of the protocol aimed at adapting the animals, they initially made three series of 10 jumps with a one-minute break between sets. On the first two days of the week the load was $30 \%$ of body weight, $40 \%$ on the third and fourth days, and $50 \%$ of bodyweight on the fifth day of the week. The depth of water was also increased progressively, starting with $100 \%$ of the length of the animal on the first day, $120 \%$ on the second and third days, and $140 \%$ on the fourth and fifth days of the week.

Starting on the second week, the sessions consisted of four series of 10 jumps with a weight equivalent to $50 \%$ of body weight, with a minute break between sets and with water depth corresponding to $140 \%$ of the body length of the $\mathrm{rat}^{27}$. The water temperature was maintained at $32 \pm 1{ }^{\circ} \mathrm{C}$.

\section{Material collection}

The animals were anesthetized with xylazine solution (Rompum ${ }^{\circledR}$-Bayer) $(10 \mathrm{mg} / \mathrm{kg})$ and ketamine hydrochloride (Ketalar $\left.{ }^{\circledR}\right)(25 \mathrm{mg} / \mathrm{kg})(0.10 \mathrm{ml}$ for each $100 \mathrm{~g}$ of body weight of the animal), and after this, their left hind legs were disarticulated and dissected to collect the calcaneal tendon. The material was moistened with physiological saline solution and taken shortly inside a thermal container to the Laboratory of Chemical Engineering - of the UFPE to perform the mechanical test.

\section{Mechanical Test}

For the mechanical test the tendon was tied to two metal connectors $(2.5 \times 3.5 \mathrm{~cm})$, one at each end. To improve the setting and prevent sliding of the anatomical structure within the connectors a drop of cyanoacrylate was applied and, subsequently, the ellipse formula was used to measure the transverse sectional area of the tendon at his medial portion. The set (connector and tendon) was then introduced into a conventional mechanical testing machine (model EMIC DL 500, Brazil) by auto-locking grips. The proximal end composed of the tendon and myotendinous junction was placed on the upper grip, while the distal end composed of the tendon and its junction with the calcaneus bone was placed on the lower jaw in anatomical position. Tendon samples were stretched to 
the breaking point, at a velocity of $0.1 \mathrm{~mm} / \mathrm{s}$, and the data were captured by a $500 \mathrm{~N}$ load cell.

From the tests were obtained load $\times$ deformation graphics which allowed the analysis of the structural property: maximum strength deformation $(\mathrm{mm})$, which quantifies the offset that the tendon achieved to reach its maximum strength. After normalization of the force by transverse sectional area and deformation by the initial length, the graphic tension $\times$ deformation was obtained, from which it was possible to evaluate the following biomechanical characteristics of the tendon: elastic modulus $(\mathrm{MPa})$, represented by the tangent of the angle formed by the most linear portion of the upslope of the graphic and indicating the viscoelastic properties of the tendon; maximum tensile strength $(\mathrm{MPa})$, calculated by the ratio between the maximum load supported by the anatomical specimen and the transverse sectional area; specific deformation (\%), obtained from the ratio of the length of the base and the maximum deformation and multiplied by 100 ; and energy/area $\left(\mathrm{N} . \mathrm{mm} / \mathrm{mm}^{2}\right)$, represented by the amount of energy absorbed by the tendon area.

\section{Statistical analysis}

The software SPSS version 20 was used. All the data were submitted to the Kolmogorov-Smirnov Normality Test and subsequently, to analysis of variance tests - oneway ANOVA and post hoc Bonferroni were applied.

The results were expressed as mean \pm standard deviation, using a reliability level of $95 \%$. Microsoft Excel - XP was also used to organize the data and to produce the graphics.

\section{RESULTS}

The monitoring of glycemic control followed the normal course of the pathology, with significant increase of blood glucose in diabetic groups (Figure 1). Even with the implementation of a training protocol the diabetic animals did not regain glycemic levels considered healthy for the species.

\section{Glucose levels}

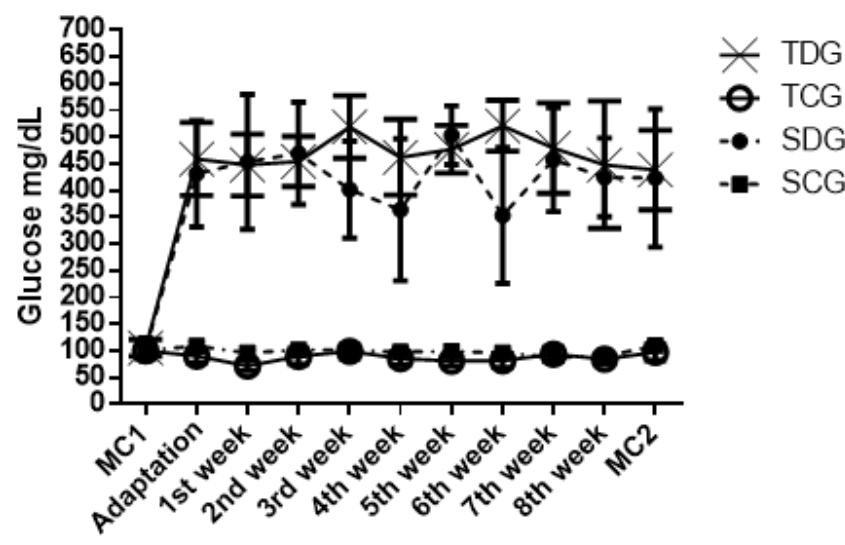

Experimental follow-up

Figure 1. Evolution of glucose levels in the experimental groups SCG - Sedentary Control Group, SDG - Sedentary Diabetic Group, TCG - Trained Control Group TDG - Trained Diabetic Group; MC - Metabolic Cage

The analysis of the biomechanical properties of the tendons (Table 1) showed that when comparing SDG to $\mathrm{SCG}$, larger values for the elastic modulus $(\mathrm{MPa})$ $(\mathrm{p}=0.000)$, for maximum tensile strength $(\mathrm{MPa})(\mathrm{p}=0.003)$, and a reduction in the values of transverse sectional area $\left(\mathrm{mm}^{2}\right)(\mathrm{p}=0.002)$ were presented by the SDG.

A greater value for transverse sectional area in the TCG $(\mathrm{p}=0.000)$ was found when comparing it to the SCG.

The animals of the TDG showed lower values of elastic modulus (MPa) ( $\mathrm{p}=0.000)$, energy/area (N. mm/ $\left.\mathrm{mm}^{2}\right)(\mathrm{p}=0.008)$ and maximum tensile strength $(\mathrm{MPa})$ $(\mathrm{p}=0.000)$, and greater values of transverse sectional area $\left(\mathrm{mm}^{2}\right)(\mathrm{p}=0.002)$ when compared to the SDG. The result of the specific deformation showed no change among the four groups evaluated $(\mathrm{p}>0.05)$.

Table 1. Evaluation of the biomechanical properties of the calcaneus tendon in the experimental groups

\begin{tabular}{|c|c|c|c|c|c|c|}
\hline \multirow[b]{2}{*}{ Groups } & \multirow[b]{2}{*}{$N$} & \multicolumn{5}{|c|}{ Biomechanical properties } \\
\hline & & $\begin{array}{l}\text { Elastic modulus } \\
\qquad(\mathrm{Mpa})\end{array}$ & $\begin{array}{c}\text { Specific deformation } \\
(\%)\end{array}$ & $\begin{array}{l}\text { Energy/ Area } \\
\left(\mathrm{N} . \mathrm{mm} / \mathrm{mm}^{2}\right)\end{array}$ & TSA $\left(\mathrm{mm}^{2}\right)$ & $\begin{array}{l}\text { Maximum Tensile Strength } \\
\text { (Mpa) }\end{array}$ \\
\hline SCG & 15 & $50.55( \pm 28.10)$ & $121.68( \pm 51.54)$ & $77.95( \pm 46.31)$ & $0.99( \pm 0.32)$ & $30.27( \pm 15.19)$ \\
\hline SDG & 15 & $124.57( \pm 70.16)^{a}$ & $87.87( \pm 36.11)$ & $106.45( \pm 51.84)$ & $0.63( \pm 0.26)^{a}$ & $55.66( \pm 29.98)^{\mathrm{a}}$ \\
\hline TCG & 14 & $42.17( \pm 25.11)$ & $95.23( \pm 69.40)$ & $38.21( \pm 26.12)$ & $1.82( \pm 0.74)^{b}$ & $23.38( \pm 13.26)$ \\
\hline TDG & 15 & $54.71( \pm 35.44)^{c}$ & $98.62( \pm 32.89)$ & $56.64( \pm 29.30)^{c}$ & $1.33( \pm 0.55)^{c}$ & $24.55( \pm 9.01)^{c}$ \\
\hline
\end{tabular}




\section{DISCUSSION}

The training protocol used in this study managed to reverse the effects of diabetes on some biomechanical parameters of the tendons assessed. While the reduction of blood glucose was not verified, the elastic modulus, maximum tensile strength, transverse sectional area and energy/area parameters were restored to normality by the applied resistance training protocol.

The degree of viscoelasticity is what gives the tendon tensile strength and is related to the values achieved by the elastic modulus. The results obtained show that this biomechanical property was greater in the diabetic animals when compared to the control animals, which resulted in an abnormal increase on the rigidity of the tendon, thus, predisposing it to breakages. Non-enzymatic glycation was probably the responsible for the increase of this value due to the covalent bonds of advanced glycation agents between collagenous structures ${ }^{8,9}$. Such results corroborate those found in other studies that showed an increase in the elastic modulus of the calcaneal tendon of rabbits undergoing non-enzymatic glycation ${ }^{28}$ and Wistar rats induced to diabetes mellitus ${ }^{29}$.

The decrease of elastic modulus to normal levels in diabetic animals subjected to resistance training demonstrated the restoration of the viscoelastic capability of the tendon, resulting from jump training in an aquatic environment. A study that used a protocol of 8 weeks of moderate aerobic training on a treadmill in diabetic rats produced lower elastic modulus values when these animals were compared to sedentary diabetic and sedentary control groups, unlike the findings of our study. However, the protocol drawn up by this author was able to restore the viscoelasticity of the tendon, thus achieving a functional result similar to ours ${ }^{21}$.

The tendon is responsible for the transmission of energy from the muscle to the bone and consequently, the production of movement. Some authors believe that the storage of elastic energy and subsequent release by the tendons acts as a mechanism to promote more economical locomotion. However, the excessive increase of the amount of energy stored by the tendon can risk the mechanical efficiency of this structure ${ }^{18}$. The reduction of this parameter in the animals of the TDG when compared to the SDG demonstrated the optimization of tendon function in transmitting energy $y^{10,16}$.

The transverse sectional area (TSA) of diabetic animals presented reduction in comparison to control animals, which may be caused by the degenerative process presented by prolonged hyperglycemia ${ }^{1,3,9,10,18,21,30}$. According to Oliveira et al. ${ }^{10}$ intense diuresis causes significant reductions on the body weight of rats, and may contribute to the decrease of the TSA.

The animals of the trained groups (TCG and TDG) show that resistance training can increase the TSA when compared to the groups SCG and SDG, respectively. Therefore, such training is effective in reversing the deleterious effects of diabetes on this parameter, suggesting that the tendon adapted to training, leading to an increase in collagen content ${ }^{31}$.

Since the maximum tension was calculated from the coefficient between the maximum load and transverse sectional area, it could be interpreted that by presenting a high value of it, the SDG has a greater ability to withstand tension before breaking. However, the TSA of this group was the smallest found, which was the main reason for the increase of this parameter. In tendons subjected to non-enzymatic glycation some authors have also found greater values of maximum tensile strength ${ }^{28}$. Our training protocol was able to reduce the tension and normalize its value when compared to the SCG. Such effect was not observed in rats subjected to an aerobic training protocol on a treadmil ${ }^{21}$.

Finally, the training protocol was not enough to normalize glycemic levels. The animals in the diabetic groups never presented glycemic levels below 200mg/ $\mathrm{dL}$ during the study. The protocol presented a sufficient load to modify the tendinous biomechanical parameters but, probably, was not strong enough to alter the glycemic metabolism promoting increase of glucose uptake by the muscles through the glucose transporters (GLUT4) ${ }^{32}$.

\section{CONCLUSION}

Independent of the increased absorption of glucose common in resistance exercises, the resistance training with progressive overload was able to restore the parameters regarding elastic modulus, maximum tensile strength, transverse sectional area and energy/area in the calcaneal tendon of diabetic animals studied with no changes on the diabetic status. These structural and biomechanical changes suggest a decrease in the deleterious effects of Diabetes Mellitus on the tendon structure when the protocol specifically works the tendon in short cycles of exercises with high overload, thus, resulting in an improvement on the energy transmission threshold of the tendon and decreasing its predisposition to rupture. 


\section{SUPPORT}

From the Conselho Nacional de Desenvolvimento Científico e Tecnológico (public notice CNPq/Universal 4768152011-8) and the Fundação de Amparo a Ciência of the state of Pernambuco (FACEPE).

\section{REFERENCES}

1. Akturk M, Karaahmetoglu S, Kacar M, Muftuoglu O. Thickness of the supraspinatus and biceps tendons in diabetic patients. Diabetes Care. 2002;25(2):408. doi: 10.2337/diacare.25.2.408

2. Oliveira RR, Mayworn SH, Oliveira MC. Existe relação da microangiopatia diabética com as alterações estruturais dos tendões? Diabetes Clín. 2003;7(6):446-9.

3. Bolton NR, Smith KE, Pilgram TK, Mueller MJ, Bae KT. Computed tomography to visualize and quantify the plantar aponeurosis and flexor hallucis longus tendon in the diabetic foot. Clin Biomech (Bristol, Avon). 2005;20(5):540-6. doi: 10.1016/j.clinbiomech.2004.12.007

4. Akturk M, Ozdemir A, Maral I, Yetkin I, Arslan M. Evaluation of Achilles tendon thickening in type 2 diabetes mellitus. Exp Clin Endocrinol Diabetes. 2007;115(2):92-6. doi: 10.1055/s-2007-955097

5. Grant WP, Sullivan R, Sonenshine DE, Adam M, Slusser JH, Carson KA, Vinik Al. Electron microscopic investigation of the effects of diabetes mellitus on the Achilles tendon. J Foot Ankle Surg. 1997;36(4):272-8.

6. Aydeniz A, Gursoy S, Guney E. Which musculoskeletal complications are most frequently seen in type 2 diabetes mellitus? J Int Med Res. 2008;36(3):505-11. doi: 10.1177/147323000803600315

7. De Oliveira RR, Lemos A, de Castro Silveira PV, da Silva RJ, de Moraes SR. Alterations of tendons in patients with diabetes mellitus: a systematic review. Diabet Med. 2011;28(8):886-95. doi: 10.1111/j.1464-5491.2010.03197.x

8. Reddy GK, Stehno-Bittel L, Enwemeka CS. Glycation-induced matrix stability in the rabbit achilles tendon. Arch Biochem Biophys. 2002;399(2):174-80. doi: 10.1006/abbi.2001.2747

9. Fox AJ, Bedi A, Deng XH, Ying L, Harris PE, Warren RF, Rodeo SA. Diabetes mellitus alters the mechanical properties of the native tendon in an experimental rat model. J Orthop Res. 2011;29(6):880-5. doi: 10.1002/jor.21327

10. De Oliveira RR, Lira KD, Silveira PV, Coutinho MP, Medeiros MN , Teixeira MF, Moraes SRA. Mechanical properties of achilles tendon in rats induced to experimental diabetes. Ann Biomed Eng. 2011;39(5):1528-34. doi: 10.1007/s10439-011-0247-z

11. Luciano E, Mello MAR. Atividade física e metabolismo de proteínas em músculo de ratos diabéticos experimentais. Rev Paul Educ Fís. 1998;12(2):202-9.

12. Oliveira CAM, Rogatto GP, Luciano E. Efeitos do treinamento físico de alta intensidade sobre os leucócitos de ratos diabéticos. Rev Bras Med Esp. 2002;8(6):219-24. doi: 10.1590/ S1517-86922002000600003
13. Kemmer FW, Berger M. The diabetic patient and sports: references and guidelines for daily practice. Ther Umsch. 1983;40(10):875-82.

14. Huang HH, Farmer K, Windscheffel J, Yost K, Power M, Wright $D E$, Stehno-Bittel L. Exercise increases insulin content and basal secretion in pancreatic islets in type 1 diabetic mice. Exp Diabetes Res. 2011;2011:481427. doi: 10.1155/2011/481427

15. Curwin SL, Vailas AC, Wood J. Immature tendon adaptation to strenuous exercise. J Appl Physiol. 1988;65(5):2297-301.

16. Shadwick RE. Elastic energy storage in tendons: mechanical differences related to function and age. J Appl Physiol. 1985;68(3):1033-40.

17. Simonsen EB, Klitgaard H, Bojsen-Moller F. The influence of strength training, swim training and ageing on the Achilles tendon and m. soleus of the rat. J Sports Sci. 1995;13(4):2915. doiu: 10.1080/02640419508732242

18. Buchanan $\mathrm{Cl}$, Marsh RL. Effects of long-term exercise on the biomechanical properties of the Achilles tendon of guinea fowl. J Appl Physiol. 2001;90(1):164-71.

19. Bezerra MA, Lemos A, Lira KD, Silveira PV, Coutinho MP, Moraes SR. Does aerobic exercise training promote changes in structural and biomechanical properties of the tendons in experimental animals? A systematic review. Biol Sport. 2012;29(4):249-54. doi: 10.5604/20831862

20. Bezerra MA, Santos de Lira KD, Coutinho MP, de Mesquita GN, Novaes KA, da Silva RT, de Brito Nascimento AK, Inácio Teixeira MF, Moraes SR. Biomechanical and structural parameters of tendons in rats subjected to swimming exercise. Int J Sports Med. 2013;34(12):1070-3. doi: 10.1055/s-0033-1345130

21. Oliveira RR, Bezerra MA, de Lira KD, Novaes KA, Teixeira MF, Chaves CC, Moraes SR. Aerobic physical training restores biomechanical properties of Achilles tendon in rats chemically induced to diabetes mellitus. J Diabetes Complications. 2012:26(3):163-8. doi: 10.1016/j.jdiacomp.2012.03.017

22. Biewener AA, Roberts TJ. Muscle and tendon contributions to force, work, and elastic energy savings: a comparative perspective. Rev Exerc Sport Sci. 2000;8(3):99-107.

23. Hof AL, Van Zandwijk JP, Bobbert MF. Mechanics of human triceps surae muscle in walking, running and jumping. Acta Physiol Scand. 2002;174(1):17-30. doi: 10.1046/j.1365-201x.2002.00917.x

24. Roberts TJ, Marsh RL. Probing the limits to muscle-powered accelerations: lessons from jumping bullfrogs. J Exp Biol. 2003;206:2567-80. doi: 10.1242/jeb.00452

25. Dall'Ago P, Silva VO, De Angelis KL, Irigoyen MC, Fazan RJr, Salgado HC. Reflex control of arterial pressure and heart rate in short-term streptozotocin diabetic rats. Braz J Med Biol Res. 2002;35(7):843-9. doi: 10.1590/S0100-879X2002000700013

26. Carvalho EN, Carvalho NAS, Ferreira LM. Experimental model of induction of diabetes mellitus in rats. Acta Cir Bras. 2003;18(no. spe):60-4. doi: 10.1590/ S0102-86502003001100009

27. Rogatto GP, Luciano E. Efeitos do treinamento físico intenso sobre o metabolismo de carboidratos. Rev Bras Ativ Fís Saúde. 2001;6(2):39-46. 
28. Reddy GK. Cross-linking in collagen by nonenzymatic glycation increases the matrix stiffness in rabbit Achilles tendon. Exp Diabesity Res. 2004;5(2):143-53. doi: 10.1080/15438600490277860

29. Bezerra MA, Nery CS, Silveira PVC, Mesquita GN, Figueiredo TG, Teixeira MFHBI, Moraes SRA. Previous physical exercise slow down the complications from experimental diabetes in the calcaneal tendon. Muscles Ligaments Tendons J. 2016;6(1):97-103. doi: 10.11138/mltj/2016.6.1.097

30. Papanas N, Courcoutsakis N, Papatheodorou K, Daskalogiannakis G, Maltezos E, Prassopoulos P. Achilles tendon volume in type 2 diabetic patients with or without peripheral neuropathy: MRI study. Exp Clin Endocrinol Diabetes. 2009;117(10): 645-8. doi: 10.1055/s-0029-1224121

31. Kjaer M, Langberg H, Miller BF, Boushel R, Crameri R, Koskinen $\mathrm{S}$, et at. Metabolic activity and collagen turnover in human tendon in response to physical activity. J Musculoskelet Neuronal Interact. 2005;5(1):41-52.

32. Pauli JR, Cintra DE, Souza CT, Ropelle ER. New mechanisms by which physical exercise improves insulin resistance in the skeletal muscle. Arq Bras Endocrinol Metab. 2009;53(4):399408. doi: 10.1590/S0004-27302009000400003 